\title{
Selected abiotic factors that influence raw cow milk freezing point depression
}

\author{
Oto Hanuš ${ }^{1}$, Kristýna Hanušová ${ }^{2}$, Marcela Vyletělová ${ }^{1}$, Tomáš Kopec ${ }^{3}$, Libor Janů ${ }^{2}$, \\ Jaroslav Kopecký ${ }^{2}$
}

\author{
${ }^{1}$ Research Institute for Cattle Breeding, Rapotín, The Czech Republic \\ ${ }^{2}$ AgriResearch, Rapotín, The Czech Republic \\ ${ }^{3}$ Czech Fleckvieh Breeders Association, Prague, The Czech Republic
}

Received November 11, 2010

Accepted January 18, 2012

\begin{abstract}
Freezing point depression (FPD) is an important property of milk that is influenced primarily by milk components connected to osmotic pressure. Under certain conditions it is possible to detect the addition of water to milk. It is necessary to have the right FPD limit in legislation for milk quality control. The aim of this study was to improve the estimation procedure of this limit. Apart from factors related to dairy cow nutrition, cattle breed and milk yield, it is important to take into account $\mathrm{CO}_{2}(6 \%)$, water steam evaporation and pasteurization under technological conditions. Bulk milk samples $(1,30,6,6,10,1$ according to experiment) from Holstein and Czech Fleckvieh breed $(1: 1)$ were used in the experiments and technologically treated. The effects of water addition (water saturated and unsaturated by $\mathrm{CO}_{2}$ ), carbon dioxide evaporation and pasteurization $\left(80^{\circ} \mathrm{C}\right.$ for $22 \mathrm{~min}$ ) were quantified. Pasteurization aggravation of FPD was $-0.00394 \pm 0.00171{ }^{\circ} \mathrm{C}(P<0.001)$. Aggravation due to carbon dioxide evaporation could be $-0.00383 \pm 0.00095{ }^{\circ} \mathrm{C}(P<0.001)$ depending on practice. Increase in FPD is recorded after milking during technological procedures of milk storage, mixing, pumping, transport shaking and warming. During FPD shift, the acuteness of FPD data sets increases. This fact should be considered in the process of deriving standard raw cow milk FPD limits. Similar experimental analysis of milk FPD technological shifts has not been performed in this way until now.
\end{abstract}

Bulk milk, extraneous water addition, pasteurization, vacuum, carbon dioxide saturation

Milk freezing point depression (FPD) is an important qualitative milk indicator. It is mostly used for the control of raw or pasteurized milk quality in terms of its incidental milk falsification by adding foreign water (AFW; extraneous water). The main effect on FPD could be caused by the addition of foreign water through defects in milking equipment. Possible effects of automatic milking systems on FPD deterioration have been published (Rasmussen and Bjerring 2005). However, there are other additional reasons for milk FPD variations beside AFW (Wiedemann et al. 1993; Buchberger 1994; Crombrugge 2003; Chládek and Čejna 2005). Average milk FPDs differ significantly among breeds and species of farm mammals, $-0.5320 \pm 0.0050$ and $-0.5221 \pm 0.0043,-0.5544 \pm 0.0293$ and $-0.6048 \pm 0.0691{ }^{\circ} \mathrm{C}$ in Holstein and Czech Fleckvieh cattle, White short-haired goat and Tsigai sheep, respectively (Genčurová et al. 2008; Macek et al. 2008). Some European Union countries are using the legislation discrimination limits of FPD for standard cow milk quality ranging from $\leq-0.520{ }^{\circ} \mathrm{C}$ to $\leq-0.505{ }^{\circ} \mathrm{C}$ (Rohm et al. 1991; Buchberger 1994; Crombrugge 2003). In the Czech Republic, the discrimination limits $\leq-0.515$ and $\leq-0.520^{\circ} \mathrm{C}$ for raw and pasteurized cow milk have been valid. Council Regulation (EC) 1234/2007 also prescribes the rule that the mean FPD value of drinking milk shall be equal to raw milk FPD mean under local conditions of the collecting area. Lactose content causes $53.8 \%$ of the milk FPD. The effect of the milk carbonic acid gas content and its evaporation may be also marked. Significant correlations $(P \leq 0.05)$ were found by Hanuš et al. (2010) e.g. between FPD and: total milk solids $(-0.50)$, true protein $(-0.43)$, whey protein $(-0.47)$, milk fat $(-0.46)$, lactose $(-0.35)$, somatic cell count $(-0.36)$ and milk citric acid (0.47). Milk citric acid content contributes essentially to FPD

Address for correspondence:

Oto Hanuš

Research Institute for Cattle Breeding Rapotín

Výzkumníkủ 267, 78813 Vikýřovice

Czech Republic
Phone: +420583392157
Fax: +420583392129
E-mail: oto.hanus@vuchs.cz
http://www.vfu.cz/acta-vet/actavet.htm 
in terms of osmotic pressure support and it is also a suitable indicator of dairy cow energy metabolism (Garnsworthy et al. 2006). However, milk FPD was not found to be influenced dramatically by fat content manipulation (Hanuš et al. 2011).

There are questions about possible changes in FPD due to milk storage after milking, its transport and industrial processing caused by business complications. In these cases, milk deliveries are sent from buyer back to seller (between dairy plants) because of unsatisfactory FPD. The aim of this paper was to study, describe and quantify milk FPD changes due to abiotic (technical) factors in various technological experiments.

\section{Materials and Methods}

One bulk raw cow milk sample (Holstein) was split into four subsamples in two rows ( $\mathrm{n}=1$ plus 4 and 4 ). These were diluted by saturated and original distilled water (without $\mathrm{CO}$, saturation) from a 0.5 to $2.0 \%$ ratio (Fig. 1). In the first case, $800 \mathrm{ml}$ of water were saturated by carbon dioxide $\left(\mathrm{CO}_{2}\right)$ at $6{ }^{\circ} \mathrm{C}$ for $24 \mathrm{~h}$ in a pressure bottle, the weight of $\mathrm{CO}_{2}$ was $7.9 \mathrm{~g}$.

Set of bulk milk samples $(n=30)$ from Holstein $(H o)$ and Czech Fleckvieh $(C F)$ breed $(1: 1)$ obtained in the winter season was pasteurized under $80^{\circ} \mathrm{C}$ for $22 \mathrm{~min}$ (Fig. 2).

In three experiments, individual raw cow milk samples ( $5 \mathrm{ml}$ of one sample in vessel) from Ho and CF cows $(1: 1)$ were used $(n=6,6$ and 10$)$.

In vacuum, $\mathrm{CO}_{2}$ and partly also water steam were exhausted using a vacuum pump at $20{ }^{\circ} \mathrm{C}(\mathrm{Figs} 3,4,5)$. Milk samples, vacuum and time were variously modified in different experiments as demonstrated in the figures. Six bulk raw cow milk (Ho and $\mathrm{CF}$ breed 1:1) and six drinking water samples were saturated by $\mathrm{CO}_{2}$ in pressure bottle for $6 \mathrm{~h}$ under refrigerator temperature of $6^{\circ} \mathrm{C}$ (Figs 6 and 7). The saturation of liquids (water and milk) was reached using one litre of the working volume and a gas bomb with $7.9 \mathrm{~g}$ and $10 \mathrm{ml}$ of the filling. This is equal to $0.1795 \mathrm{~mol}$ of $\mathrm{CO}_{2}$ and max. 7.5 MPa pressure (processor data). Calculated pressure according to actual measured paramaters (van der Waals's equation) was 5.71 MPa. Values of FPD were measured (twice) using the top cryoscopic instrument Cryo-Star automatic Funke-Gerber (Germany) as a reference method. The selected measurement mood was reference Plateau Search. Instrument regularly calibrated by standard $\mathrm{NaCl}$ solutions (ISO 5764:2002(E)). The data were processed using regression. Differences were tested by paired t-test. These are shown using box graphs: median is the central short horizontal line; the upper edge of the $1^{\text {st }}$ and $3^{\text {rd }}$ quartiles is the tetragon; variation range, maximum - minimum is the vertical line.

\section{Results}

Experimental results are shown in graphs (Figs 1-7). Significant effect $(P<0.001)$ of AFW represented a milk FPD increase by $0.006{ }^{\circ} \mathrm{C}$ (Fig. 1). A similar effect with water saturated by $\mathrm{CO}_{2}$ was $0.004{ }^{\circ} \mathrm{C}$. Significant $(P<0.001)$ increase in FPD by milk pasteurization was

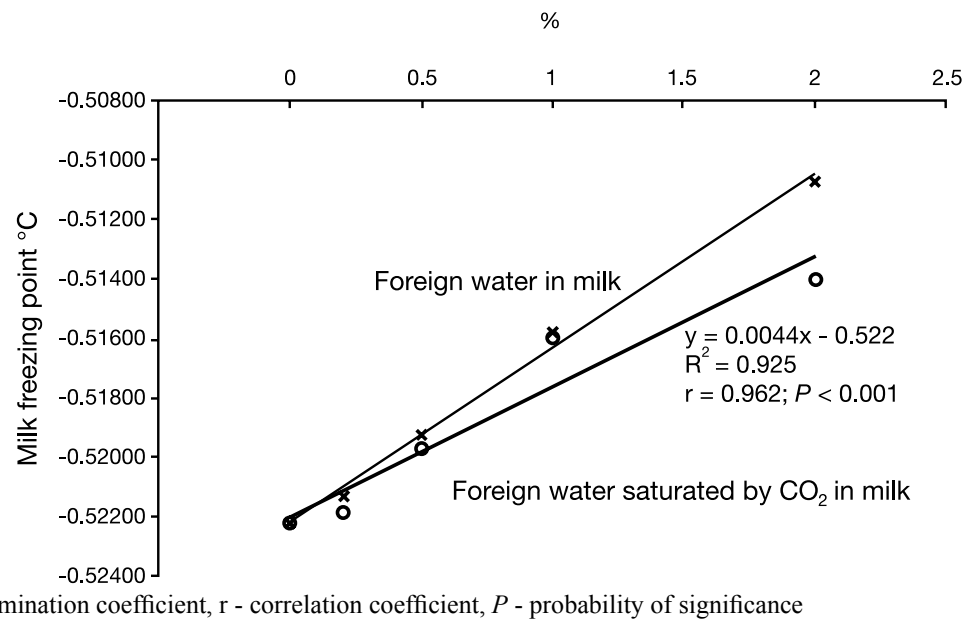

$\mathrm{R}^{2}$ - determination coefficient, $\mathrm{r}$ - correlation coefficient, $P$ - probability of significance

Fig. 1. Regression rendering of effect of weak dilution of raw cow milk by saturated (with carbon dioxide, $\mathrm{CO}_{2}$ ) and unsaturated distilled water on its freezing point depression. 


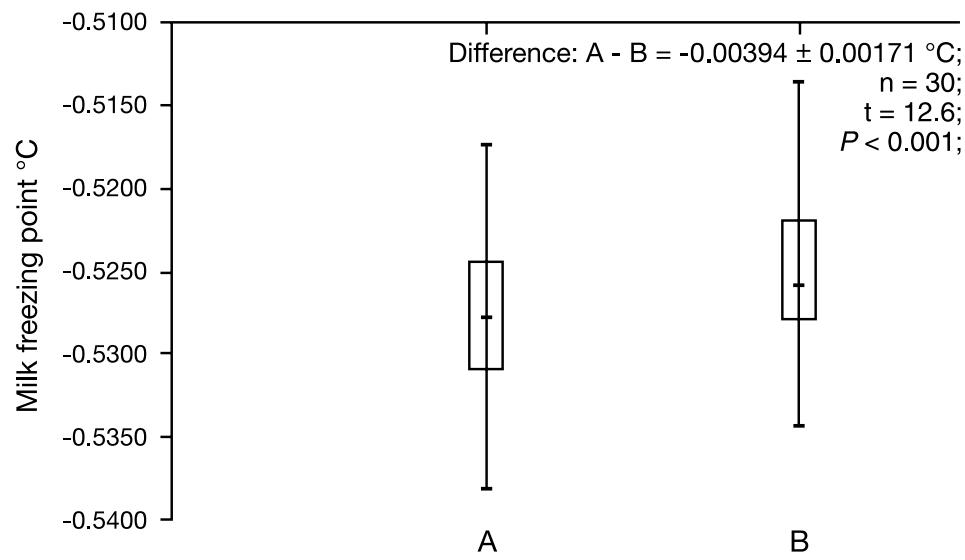

\section{Treatment}

$\mathrm{n}$ - number of cases, $\mathrm{t}$ - criterion of pair t-test, $P$ - probability of significance, A - raw cow milk, B - pasteurized milk. Pasteurization was carried out at $80^{\circ} \mathrm{C}$ for 22 minutes. Thirty bulk milk samples from Holstein and Czech Fleckvieh dairy cow herds in winter feeding season (from February to April); one sample is equal to $300 \mathrm{ml}$.

Fig. 2. Rendering of pasteurization effect on raw cow milk freezing point depression.

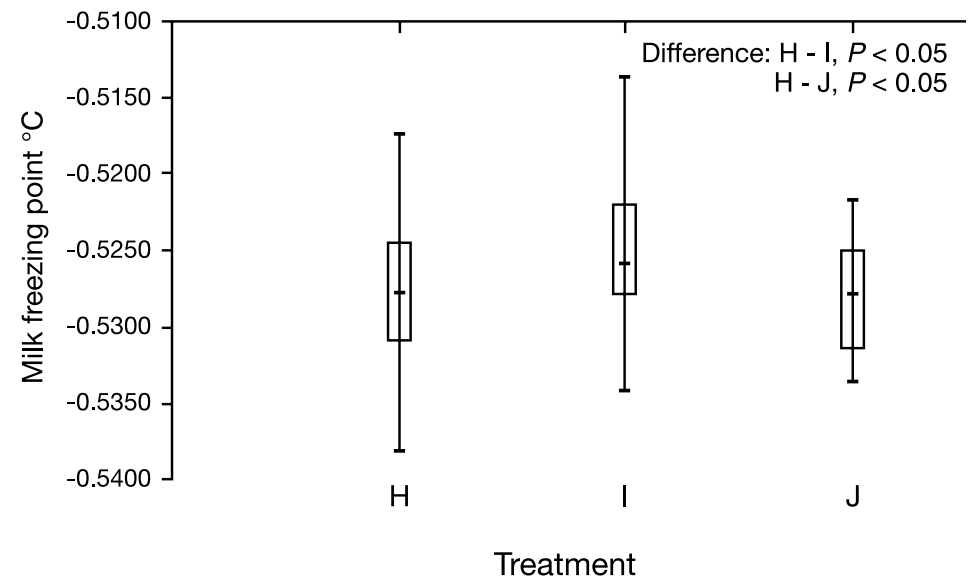

$\mathrm{H}$ - original milk, it means 6 individual raw cow milk samples from two breeds (Holstein and Czech Fleckvieh), I - $\mathrm{CO}_{2}$ evaporation, $\mathrm{J}$ - water steam evaporation. There were $5 \mathrm{ml}$ of milk in one sample on Petri dish. $\mathrm{CO}_{2}$ exhausting was performed at 40 and $80 \mathrm{kPa}$ (I and J) during 60 and 120 second of vacuum time.

Fig. 3. Graphical rendering of carbon dioxide evaporation and consequently also water steam evaporation on raw cow milk freezing point depression by vacuum and time.

$0.00394{ }^{\circ} \mathrm{C}$ (Fig. 2). We also found a significant milk FPD increase due to $\mathrm{CO}_{2}$ exhausting and consequent FPD decrease due to water steam evaporation (Figs 3, 4 and 5). In this context, the raw cow milk FPD increase by $\mathrm{CO}_{2}$ evaporation (normal content in milk is $6 \%$ ) was estimated as a practical effect with a value $0.00383{ }^{\circ} \mathrm{C}$ (Fig. 4). In the experiments shown in Figs 6 and 7 we demonstrated a significant effect of milk and water saturation by $\mathrm{CO}_{2}$ on FPD decrease under the mentioned circumstances. Milk FPD was decreased by $0.0896^{\circ} \mathrm{C}$ (Fig. 7). 


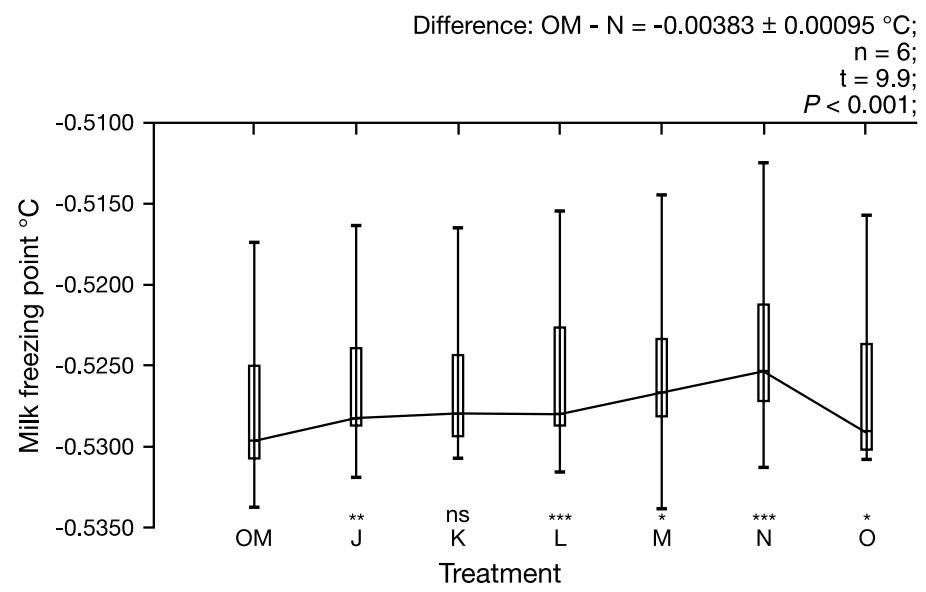

OM - original milk, it means 6 bulk (herd) raw cow milk samples from two breeds (Holstein and Czech Fleckvieh cattle breed), from $\mathrm{J}$ to $\mathrm{N}$ - $\mathrm{CO}_{2}$ evaporation, $\mathrm{O}$ - water steam evaporation. There were $5 \mathrm{ml}$ of milk in one sample. $\mathrm{CO}_{2}$ exhausting was performed at $10,20,40,60,80$ and $100 \mathrm{kPa}$ (from $\mathrm{J}$ to $\mathrm{O}$ ) with time duration of vacuum approach and its consequent decrease, up to reaching of demanded vacuum value.

Fig. 4. Graphical rendering of carbon dioxide evaporation and consequently also water steam evaporation on raw cow milk freezing point depression by vacuum and time of exposition.

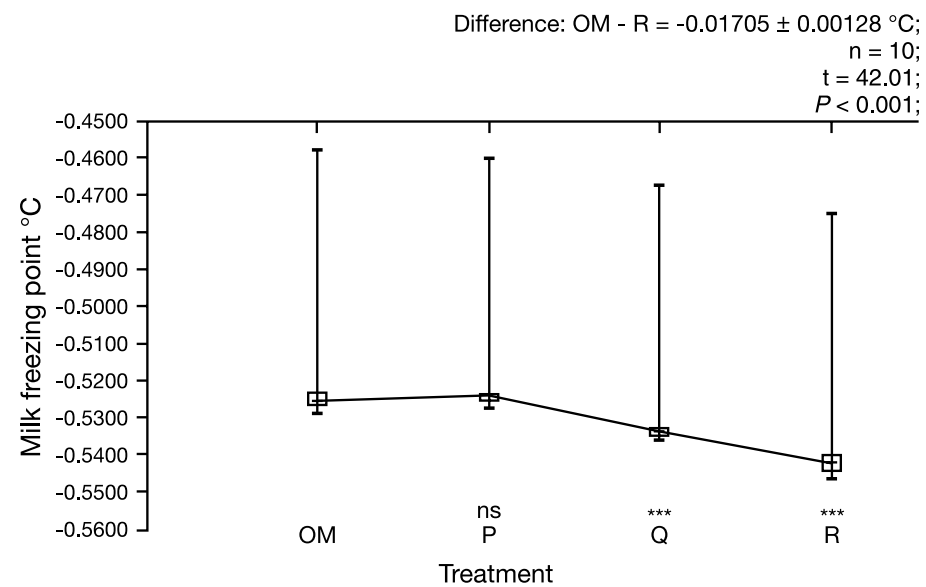

OM - original milk, it means 10 bulk (herd) raw cow milk samples from two breeds (Holstein and Czech Fleckvieh cattle breed), $\mathrm{P}$ - $\mathrm{CO}_{2}$ evaporation, $\mathrm{Q}$ and $\mathrm{R}$ - water steam evaporation. $5 \mathrm{ml}$ of milk were in one sample. There was performed addition of foreign water into one sample (10\%). $\mathrm{CO}_{2}$ exhausting was carried out at $60 \mathrm{kPa}(\mathrm{P}$; increase 20 second and decrease to $0 \mathrm{kPa} 167$ second), $100 \mathrm{kPa}$ (Q; increase 87 second, tenacity 60 second and decrease) and at $100 \mathrm{kPa}(\mathrm{R}$; increase 87 second, tenacity 120 second and decrease).

Fig. 5. Rendering of impact of carbon dioxide evaporation and consequently water steam evaporation on raw cow milk freezing point depression by vacuum and time.

\section{Discussion}

An increase in milk FPD by $0.005{ }^{\circ} \mathrm{C}$ is equal to $1 \% \mathrm{AFW}$ (extraneous water; Wiedemann et al. 1993; Buchberger 1994). In Fig. 1, the effect $(P<0.001)$ of water addition to milk is shown. In the case of water addition, the FPD increase is approximately 


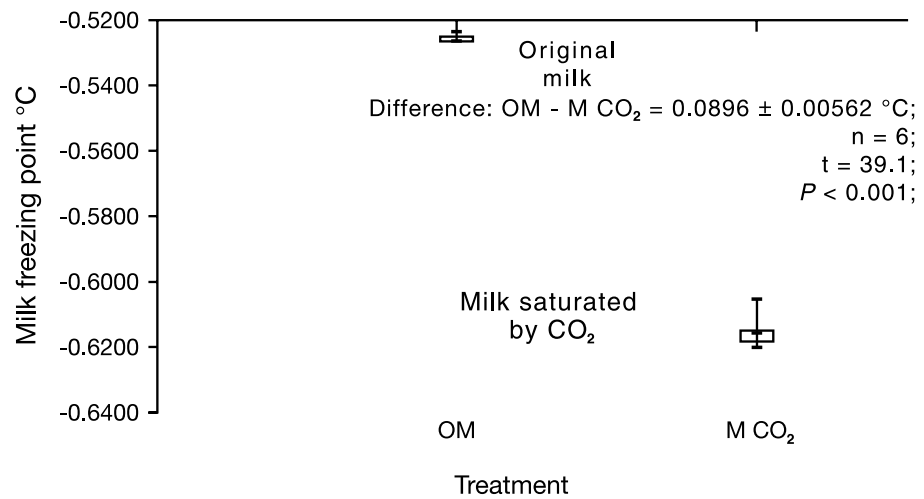

$\mathrm{OM}$ - raw cow (original) milk, $\mathrm{M} \mathrm{CO}_{2}$ - saturation by carbon dioxide.

Fig. 6. Rendering of raw cow milk saturation by carbon dioxide on milk freezing point depression value.

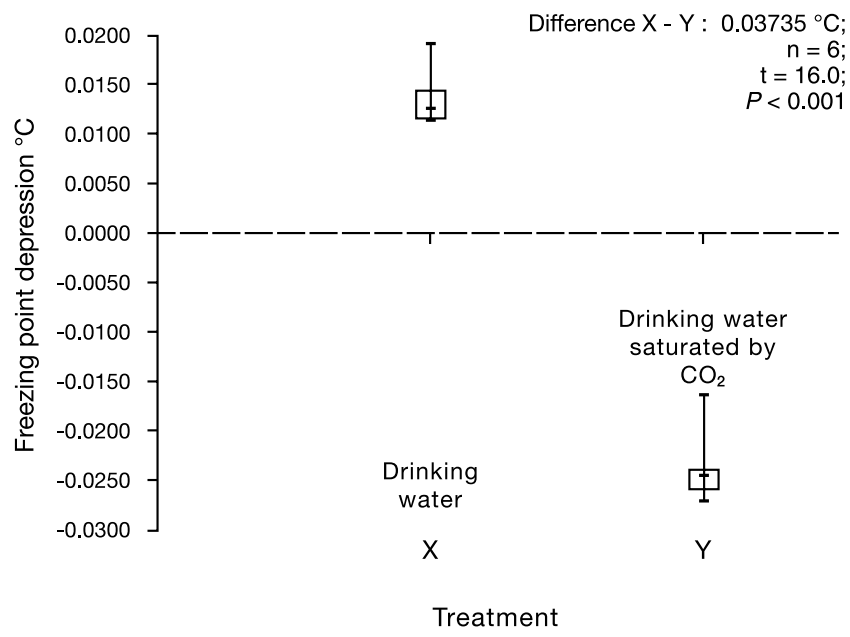

$\mathrm{X}$ - drinking water, $\mathrm{Y}$ - saturation by carbon dioxide.

Fig. 7. Rendering of impact of drinking water saturation by carbon dioxide on its freezing point depression measured by milk cryoscope.

in accordance $\left(0.006^{\circ} \mathrm{C}\right)$ with this figure. However, in the case of water saturated by $\mathrm{CO}_{2}$ the corresponding FPD increase is markedly lower (by 1/3, about $0.004{ }^{\circ} \mathrm{C}$ ) compared to pure water addition. Carbon dioxide is a natural raw milk component after milking and its volume is decreased from this time point. It can have important effects on milk FPD changes.

As it is well known, an important technological step in processing in the milk food chain is pasteurization. Fig. 2 shows the effect of pasteurization on milk FPD. There was a significant $(P<0.001)$ aggravation of FPD following pasteurization. Under the mentioned circumstances, the difference was $-0.00394 \pm 0.00171{ }^{\circ} \mathrm{C}$. This could 


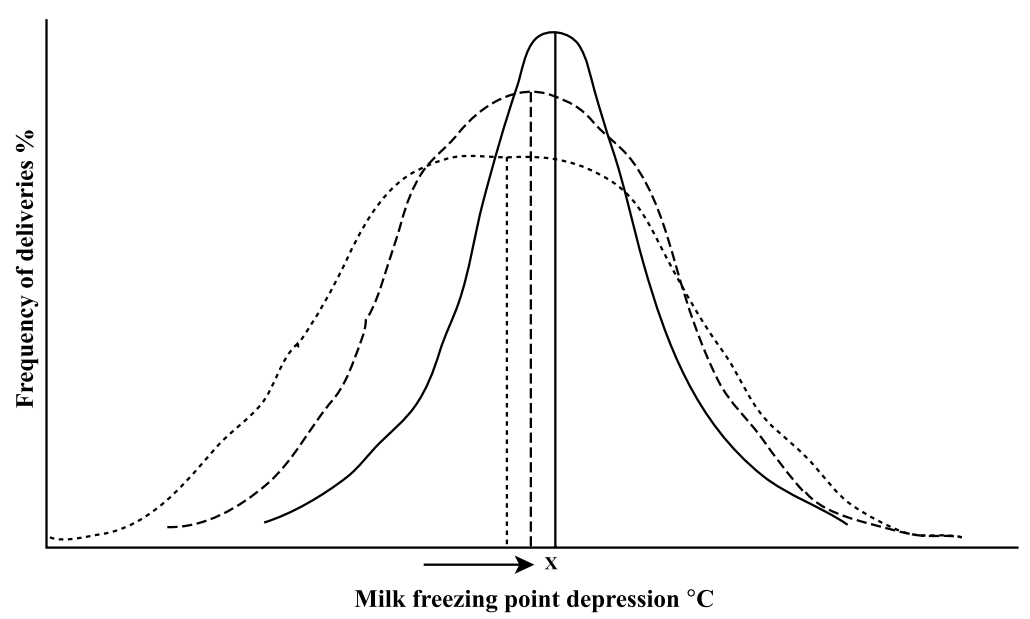

Change of freezing point depression during milk storage, transport, mixing and technological treatment in dairy plant, which can be caused by different abiotic factors, based on presumption of normal frequency distribution.

Fig. 8. Hypothetical model graph of raw cow milk FPD shift (increase) after milking.

be caused by milk protein complex heat shock, although it is possible that water steam evaporation in opened pasteurization systems (experimental or practical) could mitigate the described effect on FPD due to milk concentration. However, this effect may be very limited. Rohm et al. (1991) and Roubal et al. (2004) described higher (worse) mean FPD in pasteurized cow milk than raw bulk milk under practical conditions. Similarly, Janštová et al. (2007) determined a higher FPD for pasteurized goat milk compared to raw milk $\left(-0.5488 \pm 0.0046>-0.5513 \pm 0.0046{ }^{\circ} \mathrm{C}\right)$. These factors could explain why heat treated milk FPDs are usually worse than raw milk in practice.

Evaporation of natural $\mathrm{CO}_{2}$ from milk was simulated using vacuum generation. Using experiments with evaporation simulation, it is shown in Figs. 3, 4 and 5 that vacuum $\mathrm{CO}_{2}$ evaporation leads to FPD aggravation (increase) according to vacuum level and time. Consequently there is a technological and quality improvement (decrease) in milk FPD which is determined probably due to water steam evaporation and milk concentration. This effect was also observed in Fig. 5. One milk sample with AFW (10\%) was ranked. This fact is evident as greater FPD variation range and mean value skew in terms of frequency distribution. Experimental raw cow milk FPD aggravation (increase) by $\mathrm{CO}_{2}$ evaporation could be estimated to be about $-0.00383 \pm 0.00095{ }^{\circ} \mathrm{C}$ regarding practice under natural conditions (Fig. 4). This could be compared to $1 \%$ of AFW in milk (Wiedemann et al. 1993; Buchberger 1994; Crombrugge 2003; Rasmussen and Bjerring 2005; Hanuš et al. 2010). The effect of milk $\mathrm{CO}_{2}$ concentration on FPD is demonstrated similarly as supporting proof but in reverse (Fig. 6) by model milk $\mathrm{CO}_{2}$ saturation in a pressure vessel. Under these conditions, FPD was decreased ("improved") dramatically by $-0.0896 \pm 0.00562{ }^{\circ} \mathrm{C}$. This result was compared to the similar method of drinking water $\mathrm{CO}_{2}$ saturation (Fig. 7). From the results, in accord with Rohm et al. (1991) and as shown in Fig. 8, the FPD shifts markedly in the period after milking during technological procedures of milk storage, mixing, pumping, transport shaking and warming without AFW. During technological FPD shifts the peak of data sets for milk quality increases and variance tapers. This fact should be considered in the process of 
deriving standard raw cow milk FPD limits for legislative materials apart from specific country, breed and milk yield conditions.

In conclusion, the results can be considered in derivation procedures for objective standard raw cow FPD limits. These selected abiotic FPD factors must be considered in statistics aside from such variables as country conditions (climate, soil, feeding type), cattle breed and actual milk yield in FPD discrimination limits. This is necessary for maximal probability of objective separation of standard milk deliveries without AFW from milk with AFW. It is important in procedures for milk quality payment and control of the quality of the milk food chain. Similar solution and experimental analyses of milk FPD technological shifts have not been performed in this way until now.

\section{Acknowledgements}

This study was supported by projects MSM 2678846201 and INGO LA 09030.

\section{References}

Buchberger J 1994: To milk freezing point depression: evaluation and interpretation. Zum Gefrierpunkt der Milch: Bewertung und Interpretation. Dtsch Milchwirtsch Zeitschr 115: 376-383

Council Regulation (EC) No 1234/2007: Establishing a common organisation of agricultural markets and on specific provisions for certain agricultural products

Crombrugge van JM 2003: Freezing point. Bulletin of IDF 383: 15-22

Garnsworthy PC, Masson LL, Lock AL, Mottram TT 2006: Variation of milk citrate with stage of lactation and de novo fatty acid synthesis in dairy cows. J Dairy Sci 89: 1604-1612

Genčurová V, Hanuš O, Vyletělová M, Landová H, Jedelská R 2008: The relationships between goat and cow milk freezing point, milk composition and properties. Sci Agric Boh 39: 324-328

Hanuš O, Frelich J, Tomáška M, Vyletělová M, Genčurová V, Kučera J, Třináctý J 2010: The analysis of relationships between chemical composition, physical, technological and health indicators and freezing point in raw cow milk. Czech J Anim Sci 55: 11-29

Hanuš O, Vyletělová M, Tomáška M, Samková E, Genčurová V, Jedelská R, Kopecký J 2011: The effects of sample fat value manipulation on raw cow milk composition and indicators. Acta Univ Agric Silvic Mendel Brun LIX: 101-112

Chládek G, Čejna V 2005: The relationships between freezing point of milk and milk components and their changes during lactation in Czech Pied and Holstein cows. (In Czech) Acta Univ Agric Silvic Mendel Brun LIII: $63-70$

ISO 5764:2002(E), IDF 108:2002(E) 2002: International standard. Milk - determination of freezing point thermistor cryoscope method (Reference method) 15

Janštová B, Dračková M, Navrátilová P, Hadra L, Vorlová L 2007: Freezing point of raw and heat-treated goat milk. Czech J Anim Sci 52: 394-398

Macek A, Hanuš O, Genčurová V, Vyletělová M, Kopecký J 2008: The relations of sheep's and cow's freezing point of milk to its composition and properties. Sci Agric Boh 39: 329-334

Rasmussen MD, Bjerring M 2005: Development of bulk milk quality from herds with automatic milking system. April, ICAR Tech. Ser. - No 10, Physiological and technical aspects of machine milking, Nitra, Slovak Republic, ISSN 1563-2504: 71-86

Rohm H, Pleschberger C, Foissy F 1991: Pasteurized milk freezing point depression in Austria. Der Gefrierpunkt pasteurisierter Milch in Österreich. Ernährung / Nutrition 15: 667-671

Roubal P, Snášelová J, Buchvaldková T 2004: The freezing point of the raw and heat treated cow milk. (In Czech) Proceeding of seminar contributions of VÚCHS Rapotín: The actual problems of management in the cattle keeping: 71-76

Wiedemann M, Buchberger J, Klostermeyer H 1993: The reasons for abnormal freezing points in raw milk. $1^{\text {st }}$ and $2^{\text {nd }}$ message. Ursachen für anomale Gefrierpunkte der Rohmilch. 1. und 2. Mitteilung, Dtsch Milchwirtsch Zeitschr 114: 634-644, 656-663 